\title{
Microbiological quality of pasteurized milk and stirred yoghurt during the stages of processing
}

\author{
Elsiddeg Osman Mohamed Osman ${ }^{1}$, Al-Ghamdi Abdulaziz Yahya ${ }^{2}$ and Abdalla Mohamed Osman Mohamed \\ $3, *$
}

${ }^{1}$ Department of Dairy Production, Faculty of Animal Production, University of Khartoum, 13314, Sudan.

2 Department of Biology, Faculty of Science, Al-Baha University, Al-Baha, Saudi Arabia.

${ }^{3}$ Department of Biology, Faculty of Science, Al-Makhwah 65931, Al-Baha University, Saudi Arabia.

Publication history: Received on 08 May 2020; revised on 15 May 2020; accepted on 16 May 2020

Article DOI: https://doi.org/10.30574/wjarr.2020.6.2.0149

\begin{abstract}
The study was conducted to evaluate the microbiological quality of pasteurized milk and stirred yoghurt during the processing stages. Pasteurized milk and stirred yoghurt were manufactured in a dairy plant and subjected to microbiological analyses, in addition to analyzing the air, personal swabs, and processing water. The results indicated that total viable bacteria count (TVBC) was highest $\left(\log _{10} 5.02 \mathrm{cfu} / \mathrm{ml}\right)$ in the raw milk and $\operatorname{lowest}\left(\log _{10} 1.72 \mathrm{cfu} / \mathrm{ml}\right) \mathrm{in}$

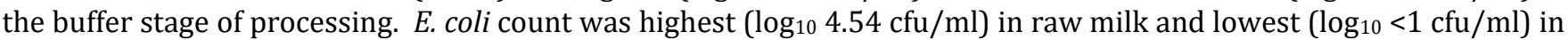
the subsequent stages of processing. E. coli was detected in the mixing stage of yoghurt $\left(\log _{10} 0.66 \mathrm{cfu} / \mathrm{gm}\right)$ and lowest $\left(\log _{10}<1 \mathrm{cfu} / \mathrm{gm}\right)$ in the subsequent stages, while yeast and mould count was $\log _{10}<1 \mathrm{cfu} / \mathrm{gm}$ in all stages. TVB and yeast and mould counts were highest $\left(\log _{10} 1.68 \mathrm{cfu} / \mathrm{m}^{2}\right.$ and $\log _{10} 1.02 \mathrm{cfu} / \mathrm{m}^{2}$, respectively) in the processing area and lowest ( $\log _{10} 1.42 \mathrm{cfu} / \mathrm{m}^{2}$ and $\log _{10} 0.68 \mathrm{cfu} / \mathrm{m}^{2}$, respectively) in the laboratory. TVBC was $\log _{10} 0.92 \mathrm{cfu} / \mathrm{m}^{2}$ and $\log _{10}$ $0.79 \mathrm{cfu} / \mathrm{m}^{2}$ in the swabs from operators and labours, respectively, while the count of $E$. coli and yeasts and moulds was $\log _{10}<1 \mathrm{cfu} / \mathrm{m}^{2}$. There was a significant effect of water source on the total dissolved solids, $\mathrm{pH}$, total hardness, and TVBC, while $E$. coli and yeast and mould counts were $\log _{10}<1 \mathrm{cfu} / \mathrm{ml}$. The study concluded that the pasteurized milk and stirred yoghurt were microbiologically acceptable and safe for human consumption because the processing conditions in the plant were acceptable.
\end{abstract}

Keywords: Pasteurized milk; Stirred yoghurt; Microbiological; Processing

\section{Introduction}

Milk is synthesized in the mammary gland and is sterile when secreted into the udder alveoli [1]. Due to its high nutritional value, neutral $\mathrm{pH}$, complex biochemical composition, and high water content, milk is an excellent medium for the growth and spread of various spoilage and pathogenic microorganisms that may cause early physicochemical and microbial degradation $[1,2,3]$. Beyond its udder secretion, microbial contamination may occur from the inside of the udder, from the outside of the udder, and the surface of the milk handling and storage equipment [4].

Milk is sterile when secreted in the udder, but becomes infected by bacteria before it leaves the udder. At this stage, the bacteria are few in number and harmless, unless the cow has mastitis. Further contamination of milk by microorganisms occurs during milking, transport, handling, and other activities [5]. Milk is safe for consumption after pasteurization but still prone to spoilage by microorganisms and quality defects [6].

Pasteurization is a method of heating milk for a predetermined period at a predetermined temperature to kill or eliminate microorganisms and to inactivate undesirable enzymes [7]. The recommendations for temperature and time

${ }^{*}$ Corresponding author: Abdalla Mohamed Osman Mohamed

Copyright (C) 2020 Author(s) retain the copyright of this article. This article is published under the terms of the Creative Commons Attribution Liscense 4.0. 
combination for pasteurization are based on the capacity of the method to degrade Coxiella burnetii [8]. Consumption of insufficiently pasteurized milk products leads to serious infections that are difficult to treat with antibiotics, and this becomes clinically significant if species isolated from the examined sample are immune to traditional antibiotics, which can, therefore, impart antibiotic resistance to the infected host without providing an alternative drug [9, 10]. Microbiological quality of pasteurized milk is the consequence of numerous factors, including raw milk quality, heat treatment employed, storage conditions, and the level of post-pasteurization contamination [3].

Yoghurt is one of the most common fermented dairy products widely consumed in the world, produced by lactic acid fermentation of milk via starter culture containing Streptococcus thermophilus and Lactobacillus bullgaricus [11, 12]. The quality of yoghurt depends on the quality of raw material and efficient control of processing stages, and the chemical and microbiological parameters determine the quality and safety of yoghurt [13]. Exposure of yogurt to microbial contamination during processing, storage, and transport without basic sanitary practices and temperature control can quickly lead to spoilage of the product, making it unacceptable for human consumption [14].

The technology of the processing dairy products in plants contributes to contamination of the air with phages, bacteria, yeasts, and moulds, and the movement of air currents from ventilation systems will contribute to the spread of microbial aerosols in food plants; thus, attention should be paid to air filtration in the plant $[15,16]$. Air quality is often a disregarded factor in milk processing plants that contribute to the quality of the final product. Microbial indoor air quality depends on a variety of factors, such as ambient air, soil, human behavior, microclimatic factors, geographic location, hygienic practices, and method of ventilation [17]. This study was conducted to assess the microbial quality of pasteurized milk and stirred yoghurt during the processing stages, in addition to assessing the processing environment.

\section{Material and methods}

\subsection{Materials}

Fresh cow milk was obtained from a dairy farm in Khartoum State, milk powder, plastic cups, and cans were obtained from the local market. The starter culture (a combination of Streptococcus thermophilus and Lactobacillus bulgaricus) was obtained from YO-MIX PRIME®, DuPont, Denmark.

\subsection{Preparation of pasteurized milk}

The milk was pre-heated at $62{ }^{\circ} \mathrm{C}$, followed by the standardization of fat and homogenization. The milk was then pasteurized at $90^{\circ} \mathrm{C}$ for 15 seconds, packaged in sterile cans, and stored at $4-10{ }^{\circ} \mathrm{C}$ till analysis.

\subsection{Preparation of stirred yoghurt}

Raw milk, skim milk powder, and stabilizer were mixed with water, accompanied by pasteurization at $95 \pm 1{ }^{\circ} \mathrm{C}$ for 4 min. The mixture was inoculated with the starter culture and incubated at $43 \pm 2{ }^{\circ} \mathrm{C}$ for $4 \mathrm{hr}$. When the pH reached 4.65 4.70 , the curd was broken and poured into sterile cups, sealed with a sterile aluminum foil, and stored at $4-10{ }^{\circ} \mathrm{C}$ till analyses.

\subsection{Sampling of air, water, and personal swabs}

The air samples were taken from three points in the plant (processing area, fresh products area, and laboratory) by placing open Petri dishes containing plate count agar and violet red bile agar media for $15 \mathrm{~min}$. The water samples were obtained from freshwater, water treated with ultraviolet, and processing water. The swabs were taken from personnel (operators and labours) as personal swabs from their hands and the swabs were mixed with a $9 \mathrm{ml}$ sterile ringer solution. The samples of air, water, and personnel swabs were incubated at $32 \pm 1^{\circ} \mathrm{C}$ for $48 \pm 2 \mathrm{hr}$ for total viable bacteria count and E. coli count and $25 \pm 1^{\circ} \mathrm{C}$ for $72 \mathrm{hr}$ for yeast and mould count.

\subsection{Sampling of milk and yoghurt}

Microbiological and physicochemical analyses were performed on a total of 937 samples (100 samples of raw milk, 100 samples of pasteurized milk, 703 samples of stirred yoghurt, 12 samples of air, 10 samples of personal swabs and 12 samples of water). 


\subsection{Microbiological examination}

\subsubsection{Preparation of the dilutions of raw and pasteurized milks}

Raw and pasteurized milk samples (1 ml each) were transferred to $9 \mathrm{ml}$ sterile ringer solution in a clean sterile test tube, then shaken to make $10^{-1}$ dilution. One milliliter from the previous dilution $\left(10^{-1}\right)$ was added aseptically to a solution of $9 \mathrm{ml}$ sterile ringer solution. This process was repeated to make serial dilutions of $10^{-1}-10^{-10}$.

\subsubsection{Preparation of the dilutions of stirred yoghurt}

A homogeneous yoghurt sample (1 gm) was transferred to a $9 \mathrm{ml}$ sterile ringer solution in a clean sterile test tube, then shaken to make $10^{-1}$ dilution. One $\mathrm{ml}$ from the dilution $\left(10^{-1}\right)$ was aseptically transferred to a 9 ml sterile ringer solution. This process was repeated to make serial dilutions of $10^{-1}-10^{-10}$.

\subsubsection{Total viable bacteria count}

The plate count agar medium was used to determine the total viable bacteria count. One milliliter of each dilution was transferred to sterile Petri dishes followed by the addition of the medium, thoroughly mixed, and incubated in an inverted position at $32{ }^{\circ} \mathrm{C}$ for $48 \mathrm{hr}[18]$.

\subsubsection{Escherichia coli count}

The count was performed using a violet red bile agar medium, and the plates were incubated in an inverted position at $32{ }^{\circ} \mathrm{C}$ for $48 \mathrm{hr}[19]$.

\subsubsection{Yeasts and moulds count}

Yeast and mould agar medium was used for the enumeration of yeasts and moulds, and the plates were incubated in an inverted position at $25^{\circ} \mathrm{C}$ for 5 days [20].

\subsection{Chemical analysis of water}

The $\mathrm{pH}$ was determined by $\mathrm{pH}$ meter (3510-Jenway), while total dissolved solids were determined by a conductivity meter (4510-Jenway).

\subsection{Hardness}

Total hardness was determined as follows: water samples $(20 \mathrm{ml})$ were measured into a volumetric flask followed by the addition of $2 \mathrm{ml}$ ammonia buffer to bring the $\mathrm{pH}$ to 10.1. Two drops of eriochrome black T indicator were added. The mixture was titrated against 0.01 M EDTA solution to the endpoint (blue colour). The total harness was calculated as follows [21]:

Total hardness $(\mathrm{mg} / \mathrm{L})=\underline{\text { Volume of EDTA } \times \mathrm{N} \times 50 \times 1000}$

The volume of the sample taken

\subsection{Statistical analysis}

Data were analyzed using Statistical Analysis Systems (SAS, ver.9) procedure to determine the effect of the processing stage on the microbiological quality of pasteurized milk and stirred yoghurt, in addition to the quality of air in the plant, personal swabs, and processing water. Mean separation was carried out using Duncan multiple range tests ( $\mathrm{p} \leq 0.05$ ).

\section{Results and discussion}

Table 1 presents the microbiological quality of pasteurized milk during the stages of processing. TVBC of raw milk was $\log _{10} 5.02 \mathrm{cfu} / \mathrm{ml}$, reduced to $\log _{10} 1.72 \mathrm{cfu} / \mathrm{ml}$ during buffer stage, followed by a gradual increase during the latest stages $\left(\log _{10} 1.74 \mathrm{cfu} / \mathrm{ml}, \log _{10} 1.75 \mathrm{cfu} / \mathrm{ml}\right.$ and $\log _{10} 1.78 \mathrm{cfu} / \mathrm{ml}$ at the start of filling, middle of filling and end of filling, respectively). E. coli count was $\log _{10} 4.54 \mathrm{cfu} / \mathrm{ml}$ in the raw milk reduced to $\log _{10}<1 \mathrm{cfu} / \mathrm{ml}$ during the subsequent stages of processing pasteurized milk due to the destruction of coliform bacteria by pasteurization temperature since coliform bacteria cannot survive at a temperature above $60^{\circ} \mathrm{C}$. 
Elsiddeg et al. / World Journal of Advanced Research and Reviews, 2020, 06(02), 120-128

Table 1 Microbiological quality $(\mathrm{cfu} / \mathrm{ml})$ of pasteurized milk during the stages of processing

\begin{tabular}{|c|c|c|c|}
\hline Parameter & & TVB & E. coli \\
\hline Raw Milk & - & $5.02^{\mathrm{a}}$ & 4.54 \\
\hline \multirow{4}{*}{$\begin{array}{l}\text { Stages of } \\
\text { Pasteurized milk }\end{array}$} & Buffer stage & $1.72^{c}$ & $<1$ \\
\hline & Start of filling & $1.74^{\mathrm{bc}}$ & $<1$ \\
\hline & Middle of filling & $1.75^{\mathrm{b}}$ & $<1$ \\
\hline & End of filling & $1.78^{\mathrm{b}}$ & $<1$ \\
\hline SE & - & 0.011 & - \\
\hline SL & - & $* * *$ & - \\
\hline
\end{tabular}

Raw milk used for the manufacture of pasteurized milk and stirred yoghurt was collected from farms applying good agricultural practice (GAP), with TVB and E. coli counts being within the permissible range leading to the production of safe products $[22,23]$. Physical hazards (dust and straw) did not occur in this stage because the raw milk was loaded in the tanker in a clean and sanitized condition. The temperature was stable due to the short time between milk transportation from the farm to the plant, leading to a reduction in bacteria count. Kassem et al. [24] reported that unclean and unsafe utensils in addition to a long time (1 - $2 \mathrm{hr}$ ) for the transportation of milk from farm to plant resulted in high bacteria count.

No chemical hazards were detected in the raw milk due to cleaning and sanitizing procedure applied in the raw milk reception unit of the plant. TVBC reported in this study was lower than the reports of Kassem et al. [24], Banik et al. [25] and Tamirat [26], while E. coli count was lower than that reported by Kassem et al. [24] and higher than that reported by Hakem et al. [27]. The lower bacterial count may be attributed to good agricultural practice (GAP) of milking and sanitization of utensils. The results of TVBC of pasteurized milk in this study are lower than those reported by Azizkhani and Tooryan [7], Banik et al. [25] and Tamirat [26] who reported values of $\log _{10} 4.11 \mathrm{cfu} / \mathrm{ml}, 1.1 \times 10^{2}-$ $1.8 \times 10^{3} \mathrm{cfu} / \mathrm{ml}$ and $4.4 \times 10^{1}-4.43 \times 10^{5} \mathrm{cfu} / \mathrm{ml}$, respectively, while E. coli count is lower than Azizkhani and Tooryan [7] who reported a value of $\log _{10} 0.01 \mathrm{cfu} / \mathrm{ml}$. The higher microbial load of raw milk resulted in higher TVBC of pasteurized milk $[24,28]$.

During the stages of processing stirred yoghurt, E. coli count was $\log _{10} 0.66 \mathrm{cfu} / \mathrm{gm}$ during mixing and $\log _{10}<1 \mathrm{cfu} / \mathrm{gm}$ during the subsequent stages of processing, while yeasts and moulds were $\log _{10}<1 \mathrm{cfu} / \mathrm{gm}$ throughout the processing stages (Table 2). During the stages of preparation of stirred yoghurt from the receipt of raw milk to the end of filling and storage, all hazards have been checked [29], therefore, chemical and physical hazards were not detected. Microbial count (yeast and mould and E. coli) reported in this study are lower than those reported by Mukisa and Kyoshabire [30] due to the application of good manufacturing practices procedure during the stages of yoghurt manufacture. The results of the analyses of yoghurt samples revealed that yeast and mould, total coliform, and fecal coliform counts were $0.77 \times 10^{2} \mathrm{cfu} / \mathrm{gm}, 28 \mathrm{NMP} / \mathrm{gm}$ and $4 \mathrm{NMP} / \mathrm{gm}$, respectively [13]. The total coliform count of authorized yogurt products purchased within Ota metropolis, Ogun State of Nigeria was and $1.0 \times 10^{3}-5.0 \times 10^{5} \mathrm{cfu} / \mathrm{ml}[31]$. 
Table 2 Microbiological quality (cfu/gm) of stirred yoghurt during the stages of processing

\begin{tabular}{llll}
\hline Parameter & & E. coli & Yeasts and moulds \\
\hline & Mixing stage & 0.66 & $<1$ \\
& After pasteurization & $<1$ & $<1$ \\
& During fermentation & $<1$ & $<1$ \\
Stages of yoghurt & After cooling & $<1$ & $<1$ \\
manufacture & Start of filling & $<1$ & $<1$ \\
& Middle of filling & $<1$ & $<1$ \\
& End of filling & $<1$ & $<1$ \\
\hline
\end{tabular}

Table 3 presents the microbiological quality of air in different areas of the plant (processing, fresh products, and the laboratory). TVBC was not significantly affected $(\mathrm{P}>0.05)$ by the area from which air was sampled, although the highest count $\left(\log _{10} 1.68 \mathrm{cfu} / \mathrm{m}^{2}\right)$ was in the processing area and the lower count was in the laboratory $\left(\log _{10} 1.42 \mathrm{cfu} / \mathrm{m}^{2}\right) . \mathrm{Yeast}$ and mould count was significantly $(\mathrm{P}<0.001)$ higher in the processing area $\left(\log _{10} 1.02 \mathrm{cfu} / \mathrm{m}^{2}\right)$ and lower in the laboratory $\left(\log _{10} 0.68 \mathrm{cfu} / \mathrm{m}^{2}\right)$.

Table 3 Microbiological quality $\left(\mathrm{cfu} / \mathrm{m}^{2}\right)$ of the air in the plant

\begin{tabular}{llll}
\hline \multicolumn{2}{l}{ Parameter } & TVB & Yeasts and moulds \\
\hline \multirow{2}{*}{ Area } & Processing area & $1.68^{\mathrm{a}}$ & $1.02^{\mathrm{a}}$ \\
& Fresh products area & $1.67^{\mathrm{a}}$ & $0.93^{\mathrm{ab}}$ \\
$\mathrm{SE}$ & Laboratory & $1.42^{\mathrm{a}}$ & $0.68^{\mathrm{b}}$ \\
$\mathrm{SL}$ & - & 0.035 & 0.078 \\
\hline \multicolumn{3}{l}{} & Means in each column bearing similar superscripts are not significantly different $(\mathrm{P}>0.05)$
\end{tabular}

The microbial (TVB and yeast and mould) count in the processing area, the fresh products area, and in the laboratory was within the permissible limit according to the parameters of the plant by using air purifiers in the processing area to produce a safe product. The mean TVB and yeast and mould counts are lower than those reported by Salustiano et al. [15]. TVBC ranged from 6-20 colonies (production hall) to 12-36 colonies (packaging hall), suggesting the poorer microbiological quality of air in the packaging hall. A similar trend was evident in the total number of airborne moulds (3-9 colonies in the production hall, and 7-15 colonies in the packaging hall) since the air in the packaging hall contained more moulds than air in the production hall [16].

The reception area in the dairy plant had a significantly higher aerobic count, with no significant difference in the pasteurization and packaging areas, and the yeast and mould count was significantly lower in the pasteurization area compared to reception and packaging areas [17]. The analysis of the surfaces and air of butter, whey, powders, and dispatch departments showed a good hygiene quality concerning total viable and yeast and mould counts [32].

The microbial quality of personal swabs of the personnel in the plant indicated that TVBC was higher in samples from operators $\left(\log _{10} 0.92 \mathrm{cfu} / \mathrm{m}^{2}\right)$ compared to labours $\left(\log _{10} 0.79 \mathrm{cfu} / \mathrm{m}^{2}\right)$, although the difference was not significant. $E$. coli and yeast and mould counts were $\log _{10}<1 \mathrm{cfu} / \mathrm{m}^{2}$ in samples from both operators and labours (Table 4). The results of the microbiological count of the personnel (TVB, E. coli, and yeasts and moulds) are lower than those reported by Aarnisalo et al. [33]. The microbiological counts are within the limits due to the application of good manufacturing practices such as hygiene station, liquid soap application, alcohol, chlorine, safety shoes, hair net, and gloves. 
Table 4 Microbiological quality $\left(\log _{10} \mathrm{cfu} / \mathrm{m}^{2}\right)$ of personal swabs

\begin{tabular}{lllll}
\hline Parameter & & TVB & E. coli & Yeasts and moulds \\
\hline \multirow{2}{*}{ Employees } & Operators & $0.92^{\mathrm{a}}$ & $<1$ & $<1$ \\
& Labours & $0.79^{\mathrm{a}}$ & $<1$ & $<1$ \\
$\mathrm{SE}$ & - & 1.20 & - & - \\
$\mathrm{SL}$ & - & $\mathrm{NS}$ & - & - \\
\hline \multicolumn{5}{r}{} \\
\multicolumn{2}{r}{ Means in each column bearing similar superscripts are not significantly different (P>0.05) } \\
\end{tabular}

TVBC of the processing water showed no significant variation in the count between raw water, water after UV treatment, and processing water $\left(\log _{10} 0.52 \mathrm{cfu} / \mathrm{ml}, \log _{10} 0.64 \mathrm{cfu} / \mathrm{ml}\right.$, and $\log _{10} 0.52 \mathrm{cfu} / \mathrm{ml}$, respectively). E. coli and yeast and mould counts were $\log _{10}<1 \mathrm{cfu} / \mathrm{ml}$ (Table 5). Total dissolved solids, $\mathrm{pH}$ and total hardness were not significantly affected $(\mathrm{P}>0.05)$ by the source of water, although slightly higher total dissolved solids content was reported in the water after UV treatment (2.36 ppm), while the $\mathrm{pH}$ was slightly higher (7.81) in the raw water and the total hardness was higher (1.51 mg/L) in the raw water and water after UV treatment (Table 5).

Table 5 Microbiological $\left(\log _{10} \mathrm{cfu} / \mathrm{ml}\right)$ and chemical quality of processing water

\begin{tabular}{|c|c|c|c|c|c|}
\hline \multirow[b]{2}{*}{ Parameters } & \multicolumn{3}{|c|}{ Source of water } & \multirow[b]{2}{*}{ SE } & \multirow[b]{2}{*}{ SL } \\
\hline & Raw water & $\begin{array}{l}\text { After UV } \\
\text { treatment }\end{array}$ & $\begin{array}{l}\text { Processing } \\
\text { water }\end{array}$ & & \\
\hline Total dissolved solids (ppm) & $2.35^{\mathrm{a}}$ & $2.36^{\mathrm{a}}$ & $2.34^{\mathrm{a}}$ & 0.036 & NS \\
\hline $\mathrm{pH}$ & $7.81^{\mathrm{a}}$ & $7.70^{\mathrm{a}}$ & $7.68^{\mathrm{a}}$ & 0.040 & NS \\
\hline Total hardness (mg/L) & $1.51^{\mathrm{a}}$ & $1.51^{\mathrm{a}}$ & $1.48^{\mathrm{a}}$ & 0.081 & NS \\
\hline TVB & $0.52^{\mathrm{a}}$ & $0.64^{\mathrm{a}}$ & $0.52^{\mathrm{a}}$ & 0.011 & NS \\
\hline E. coli & $<1$ & $<1$ & $<1$ & - & - \\
\hline Yeasts and moulds & $<1$ & $<1$ & $<1$ & - & - \\
\hline
\end{tabular}

The quality of water (from raw to processing) was checked to assure the safety of the final product. The $\mathrm{pH}$ and total hardness are lower than those reported by Simpi et al. [34], while total dissolved solids are higher. TVB, E. coli, and yeast and mould counts of processing water in this study are lower than those reported by Rompre et al. [35]. No physical hazards were detected in the manufacturing water due to the use of membrane filters in the processing units which separated the foreign materials. The results of the analysis of raw materials, production water, equipment washing water, and rinsing water in 30 units of artisanal and semi-industrial dairies in Ouagadougou showed a noncompliance in $70 \%$ of dairies, and $83.3 \%$ of the raw materials were of unsatisfying quality. The rinsing waters of the equipment were nonconforming in $76.7 \%$ of the dairies [36].

\section{Conclusion}

The raw milk used for the manufacture of pasteurized milk and stirred yoghurt was collected from farms applying good agricultural practice (GAP), with TVB and E. coli counts being within permissible range leading to the production of safe products. The microbial (TVB and yeast and mould) count in the processing area, the fresh products area and in the laboratory was within the permissible limit. The quality of water (from raw to processing) was within the permissible limit so that the final products are safe. 


\section{Compliance with ethical standards}

\section{Acknowledgments}

The authors acknowledge the cooperation of the personnel in the dairy plant during data collection.

\section{Disclosure of conflict of interest}

The authors declare no conflict of interest.

\section{References}

[1] Hadžić V, Bačić, A and Ahmetović N. (2017). Microbiological analysis of pasteurized and sterilized milk with emphasis on the impact of storage time and temperature on the growth and development of microorganisms. Congress on Food Quality and Safety, Health and Nutrition - Nutricon, Skopje, Macedonia, 18-22.

[2] Hassan GM, Meshref AMS and Gomaa SM. (2015). Microbiological quality and safety of fluid milk marketed in Cairo and Giza Governorates. Current Research in Dairy Sciences, 7 (1), 18-25.

[3] Sarkar S. (2015). Microbiological considerations: pasteurized milk. International Journal of Dairy Science, 10 (5), 206-218.

[4] Dahal LR, Karki DBN and Shah R. (2010). Total bacterial counts of raw milk in Eastern Terai of Nepal. The Journal of Agriculture and Environment, 11, 46-50.

[5] Kallço I and Ajçe S. (2014). Microbiological evaluation study of milk and dairy products in the city of Korça, Albania. The 2nd International Conference on Research and Education - "Challenges Toward the Future" (ICRAE2014), 30-31 May 2014, University of Shkodra "Luigj Gurakuqi”, Shkodra, Albania.

[6] Kable ME, Srisengfa Y, Laird M, Zaragoza J, McLeod J, Heidenreich J and Marco ML. (2016). The core and seasonal microbiota of raw bovine milk in tanker trucks and the impact of transfer to a milk processing facility. mBio, 7(4), e00836-16.

[7] Azizkhani M and Tooryan F. (2017). Chemical and microbial quality of Iranian commercial pasteurized milk samples at their expiration date. Journal of Food Quality and Hazards Control, 4, 53-57.

[8] Lejeune JT and Rajala-Schultz PJ. (2009). Food safety: unpasteurized milk: a continued public health threat. Clinical Infectious Diseases, 48(1), 93-100.

[9] Okpalugo J, Ibrahim K, Izebe KS and Inyang US. (2008). Aspects of microbial quality of some milk products in Abuja, Nigeria. Tropical Journal of Pharmaceutical Research, 7 (4), 1169-1177.

[10] Rad AH, Javadi M, Kafil HS, Pirouzian HR and Khaleghi M. (2019). The safety perspective of probiotic and nonprobiotic yoghurts: a review. Food Quality and Safety, 3, 9-14.

[11] Agu KC, Archibong EJ, Anekwe DC, Ago CA, Okafor AC and Awah NS. (2014). Assessment of bacteria present in yoghurt sold on Awka metropolis. Scholars Journal of Applied Medical Sciences, 2(6D), 3071-3075.

[12] De N, Goodluck TM and Bobai M. (2014). Microbiological quality assessment of bottled yogurt of different brands sold in Central Market, Kaduna Metropolis, Kaduna, Nigeria. International Journal of Current Microbiology and Applied Sciences, 3(2), 20-27.

[13] Ferrão JL and Pitrosse GM. (2018). Chemical and microbiological quality evaluation of yoghurt produced and marketed in Chimoio, Mozambique. Food and Nutrition Journal, 3, 163.

[14] Pal M, Mulu S, Tekle M, Pintoo SV and Prajapati JP. (2016). Bacterial contamination of dairy products. Beverage and Food World, 43(9), 40-43.

[15] Salustiano VC, Andrade NJ, Brandão SCC, Azeredo RMC and Lima S AK (2003). Microbiological air quality of processing areas in a dairy plant as evaluated by the sedimentation technique and a one-stage air sampler. Brazilian Journal of Microbiology, 34, 255-259.

[16] Memisi N, Moracanin SV and Milijasevic M. (2019). The influence of air hygiene on microbiological safety of butter. The 60th International Meat Industry Conference MEATCON2019. IOP Conf. Series: Earth and Environmental Science, 333, 012076. 
[17] Vinayananda CO, Deepak SJ, Rongsensusang, Elango A, Porteen K, Apparao V and Dhanalakshmi B. (2018). Analysis of microbial quality of the air in meat and dairy plants by impaction technique. Bulletin of Environment, Pharmacology and Life Sciences), 7 (11), 07-13.

[18] Houghtby AG, Maturin LJ and Koenig KE. (1992). Microbiological count methods. In: Marshal RT (Ed), Standard Methods for the Examination of Dairy Products, $16^{\text {th }}$ Edn. American Public Health Association, Washington, DC, USA, 213-246.

[19] Christen LG, Davidson PM, McAllister JS and Roth LA. (1992). Coliform and other indicator bacteria. In: Marshal RT (Ed), Standard Methods for the Examination of Dairy Products, $16^{\text {th }}$ Edn. American Public Health Association, Washington, DC, USA, 247-269.

[20] Frank FJ, Christen LG and Bullerman LB. (1992). Tests for groups of microorganisms. In: Marshal RT (Ed), Standard Methods for the Examination of Dairy Products, 16 ${ }^{\text {th }}$ Edn. American Public Health Association, Washington, DC, USA, 271-286.

[21] AOAC. (1990). Official Methods of Analysis of The Association of Official Analytical Chemists. 15 th Edition. Association of Official Analytical Chemists, Virginia, USA, 955 - 972.

[22] El-Hofi M, El-Tanboly E and Ismail A. (2008). Implementation of the hazard analysis critical control point (HACCP) system to UF white cheese production line. Internet Journal of Food Safety, 10, 1-8.

[23] Kamel B, Boubaker K and Attia H. (2013). Implementation of ricotta cheese production process in Tunisia. International Food Research Journal, 20(5), 2343-2348.

[24] Kaseem M, Salem E, Ahwal MA, Sadik AM, Saddik M and Gomaa NF. (2002). Application of hazard analysis and critical control point system in the dairy industry. Eastern Mediterranean Health Journal, 8(1), 114-128.

[25] Banik SK, Das KK and Uddin MA. (2014). Microbiological quality analysis of raw, pasteurized, UHT milk samples collected from different locations in Bangladesh. Stamford Journal of Microbiology, 4(1), 5-8.

[26] Tamirat T. (2018). Microbiological quality analysis of raw and pasteurized milk samples collected from Addis Ababa and its surrounding in Ethiopia. Approaches in Poultry, Dairy and Veterinary Sciences, 4(5), $374-381$.

[27] Hakem A, Yabrir B, Khelef D, Laoun A, Moulfok F, El-Gallas N, Titouche Y and Ben Aissa R. (2012). Evaluation of microbial quality of raw milk into two dairies Mitidja's farms (Algeria). Bulletin USAMV, Veterinary Medicine, 69 (1-2), 272-281.

[28] Salman AMA and Hagar ME. (2013). Some bacterial and physical quality of pasteurized milk in Khartoum. Journal of Applied and Industrial Sciences, 1 (2), 30-37.

[29] Musaj A, Bijo B, Hoxha A and Gjinovci V. (2012). The study of HACCP in dairy-yoghurt product. Macedonian Journal of Animal Science, 2 (3), 313-320.

[30] Mukisa IM and Kyoshabire R. (2010). Microbiological, physicochemical and sensorial quality of small-scale produced stirred yoghurt on the market in Kampala city, Uganda. Journal of Nutrition and Food Science, 40(4), 409-418.

[31] Taiwo OS, Afolabi RO, Oranusi SU, Owolabi JB, Oloyede AR, Isibor PO, Omonigbehin EA, Popoola JO, Obafemi YD, Ejoh SA, Akinduti PA, Adekeye BT, Olorunshola SJ, Awotoye OA, Kuye AO and Ige OJ. (2018). Microbiological assessment of commercial yogurt sold in Ota metropolis, Ogun State, Nigeria. 8th International Biotechnology Conference, Exhibition and Workshop. IOP Conf. Series: Earth and Environmental Science, 210, 012019.

[32] Zacharski KA, Southern M, Ryan A and Adley CC. (2018). Evaluation of an environmental monitoring program for the microbial safety of air and surfaces in a dairy plant environment. Journal of Food Protection, 81(7), 11081116.

[33] Aarnisalo K, Tallavaara K, Wirtanen G, Maijala R and Raaska L. (2008). The hygienic working practices of maintenance personnel and equipment hygiene in the finished food industry. Food Control, 17, 1001-1011.

[34] Simpi B, Hiremath SM, Murthy KNS, Chandrashekarappa KN, Patel AN and Puttiah ET. (2011). Analysis of water quality using physico-chemical parameters Hosahalli tank in Shimoga district, Karnataka, India. Global Journal of Science Frontier Research, 11(30), 30-34.

[35] Rompré A, Servais P, Baudart J, de-Roubin MR and Laurent P. (2010). Detection and enumeration of coliforms in drinking water: current methods and emerging approaches. Journal of Microbiological Methods, 49(1), 31-54. 
[36] Millogo-Dah PA, Nikièma F, Cissé H, Somda A, Ouédraogo AW, Tankoano A, Somda NS, Sawadogo-Lingani H and Savadogo A. (2019). Evaluation of food safety management in artisanal and semi-industrial dairies of Ouagadougou, Burkina Faso. Journal of Food Security, 7(3), 80-89.

\section{How to cite this article}

Elsiddeg OMO, Al-Ghamdi AY and Abdalla MOM. (2020). Microbiological quality of pasteurized milk and stirred yoghurt during the stages of processing. World Journal of Advanced Research and Reviews, 06(2), 120-128. 